\title{
LITERASI PELAJAR SMA TENTANG INTERNASIONALISASI PERGURUAN TINGGI
}

\author{
Rino A Nugroho, Apneta Vionuke, Septyanto G Prakoso, Likha S Anggreni, Monika S Yuliarti \\ Fakultas IImu Sosial dan IImu Politik, Universitas Sebelas Maret \\ rino.nugroho@staff.uns.ac.id
}

\begin{abstract}
Abstrak
Pembangunan suatu negara ditentukan oleh kualitas sumber daya manusia. Dalam banyak kasus, untuk meningkatkan kualitas sumber daya manusia, beberapa orang memilih untuk mendapatkan gelar yang lebih tinggi di universitas di luar negeri. Sayangnya, sebagian besar siswa memilih untuk tidak kembali ke negara asal mereka dan lebih memilih untuk tinggal dan bekerja di negara tempat mereka mendapatkan negara mereka. Fenomena tertentu ini disebut brain drain. Untuk mengurangi kemungkinan brain drain terjadi, kualitas universitas lokal harus disinkronkan dengan standar internasional. Namun, walaupun ada beberapa universitas berstandar internasional di dalam negeri, ada kemungkinan bahwa calon siswa / lulusan sekolah menengah masih belum tahu tentang pentingnya keterpaparan internasional dan kualitas dalam memilih universitas masa depan mereka. Penelitian ini dilakukan untuk meneliti literasi informasi siswa SMA tentang internasionalisasi tingkat yang lebih tinggi. Ini dianggap sebagai proyek percontohan untuk menemukan korelasi literasi informasi siswa sekolah menengah dan status universitas tingkat internasional. Penelitian ini dilakukan dengan melakukan survei terhadap siswa di dua sekolah menengah terkemuka di Solo. Sampel diambil dengan menggunakan metode convenience sampling, mengingat sifat penelitian untuk menemukan fenomena sosial. Hasil penelitian menunjukkan bahwa untuk kriteria tertentu, siswa sudah tahu tentang masalah ini, tetapi untuk beberapa kriteria lain mereka masih memiliki informasi minimum. Penelitian ini juga dapat menemukan media yang banyak digunakan oleh siswa sebagai sarana untuk meningkatkan literasi informasi.
\end{abstract}

Kata kunci: brain drain, internasionalisasi pendidikan tinggi, literasi informasi, media.

\begin{abstract}
It is a fact that the development of a country is decided by the quality of the human resources. In a lot of cases, to increase the quality of human resources, some individuals choose to get their higher degree in the universities overseas. Unfortunately, most of these students choose not to go back to their home country and prefer to stay and work in the the country where they get their country instead. This certain phenomenon is called brain drain. To reduce the possibility of brain drain for happening, the quality of local university should be synchronized with international standard. However, eventhough there are some internationally-standard universities domestically, there is a possibilities that the potential students/high school graduates still do not know about the importance of international exposure and quality in choosing their future university. This research is conducted to scrutinize the information literation of high school students about higher degree internationalization. This is considered a pilot project to discover the correlation of information literation of high school students and the status of a international-level university. The research is done by conducting survey towards students in two reputable high schools in Solo. Sample is taken by applying convenience sampling method, considering the nature of the research to discover a social phenomenon. The result of the research shown that to certain criteria, the students already know about the issue, but for some other criteria they still possess a minimum information. This research also able to find the me-
\end{abstract}


dia which mostly used by the students as the means to increase information literation.

Keywords: higher education internationalization, information literacy, media.

\section{Pendahuluan}

Brain drain merupakan suatu fenomena migrasi internasional yang biasanya dilakukan oleh para intelektual. Fenomena ini umumnya terjadi pada negara-negara sedang berkembang yang masih memiliki kualitas pendidikan rendah. Sebagai konsekuensinya para intelektual melakukan migrasi internasional untuk mengembangkan potensinya di negara-negara maju yang memiliki kualitas pendidikan yang jauh lebih baik dari negara dimana ia berasal. Hal ini terjadi karena potensi yang mereka miliki tidak dapat berkembang di negaranya sendiri karena kualitas pendidikan yang masih rendah. Selain memenuhi kebutuhannya akan pendidikan yang lebih baik, para intelektual itu juga mempertimbangkan aspek peluang karier yang relatif lebih baik di negara-negara maju. Hal ini menyebabkan terjadinya migrasi besar-besaran yang dilakukan oleh para intelektual sehingga menjadikan hilangnya modal manusia terampil dimana kemudian hari brain drain menjadi malapetaka bagi negara-negara pengirim yang biasanya didominasi oleh negara berkembang. (Giousmpaasoglou. C dkk, 2017).

Perguruan tinggi yang bertaraf internasional di negara maju memberikan pengalaman baru bagi mahasiswa yang belajar disana, seperti selama proses belajar mereka menerima akses ke teknologi tinggi bertaraf internasional dan dibiasakan dengan penelitian lanjutan dengan peluang pekerjaan yang ditawarkan sesuai dengan potensinya. Pengalaman ini membuat para calon siswa melakukan analisis yang secara mendalam mengenai pengembangan secara profesional bagi masa depan mereka dan menghasilkan keinginan mereka untuk pindah ke luar negeri setelah menyelesaikan pendidikan tinggi (Sieglin.V dkk, 2010). Kesempatan belajar dengan perguruan tinggi yang lebih bereputasi dengan kesempatan kerja yang lebih baik membuat para calon siswa yang potensial mengembangkan negaranya beralih untuk sekolah dan kemudian menetap luar negeri (De Wit, 2015). Ditambah lagi masih rendahnya tingkat apresiasi bagi para tenaga ahli di negara berkembang membuat mereka yang memiliki potensi semakin berani untuk meninggalkan negaranya sendiri demi mendapat kehidupan yang lebih baik di negara maju. Untuk mencegah semakin hilangnya para ilmuwan, tenaga ahli, dan para intelektual perlu dilakukan upaya dalam peningkatan kualitas pendidikan terutama mengupayakan perguruan tinggi di Indonesia yang bertaraf internasional. Upaya ini dapat mendukung para tenaga ahli dalam mengembangkan potensi yang dimilikinya sehingga mereka tidak perlu melakukan "pelarian" ke luar negeri.

Di era teknologi seperti ini, tidak dapat dipungkiri pendidikan menjadi prioritas utama bagi setiap individu. Setiap tahun angka siswa sekolah menengah atas yang bersaing untuk 
mendapatkan kursi di perguruan tinggi meningkat. Hal tersebut menunjukkan bahwa kesadaran akan pentingnya pendidikan sudah mulai tumbuh pada masyarakat Indonesia. Disinilah peran perguruan tinggi untuk menyerap, menciptakan dan menghasilkan sumber daya manusia yang terdidik dan memiliki keahlian. Hal ini dikarenakan perguruan tinggi merupakan instrumen penting untuk pembangunan sosial ekonomi, dan salah satu strategi untuk meningkatkan dan memenuhi syarat pendidikan tinggi adalah internasionalisasi (Alemu.S.K, 2014). Semakin berkembangnya teknologi maka semakin mudah pula masuknya globalisasi, pengaruh globalisasi yang terjadi dalam berbagai bidang tidak dapat dilepaskan dari internasionalisasi yang harus diikuti oleh setiap negara agar tidak tertinggal dari negara-negara lainnya. Seperti halnya dalam bidang pendidikan, saat ini perguruan tinggi di Indonesia dituntut untuk memiliki skala berkelas dunia.

Peningkatan mutu ini dilakukan pada berbagai bidang yang menjadi bagian dari perguruan tinggi termasuk didalamnya kualitas tenaga pendidik, kualitas mahasiswa, dan perpustakaan agar menghasilkan perguruan tinggi berskala dunia atau lebih dikenal dengan istilah World Class University. Dalam mewujudkannya dibutuhkan proses internasionalisasi perguruan tinggi di Indonesia. Internasionalisasi telah menjadi agenda umum di seluruh dunia hal ini berpengaruh pula pada perguruan tinggi yang ada (Lee.W.O, 2014). Internasionalisasi perguruan tinggi merupakan suatu upaya perbaikan terhadap sistem pendidikan yang ada saat ini sehingga dapat menghasilkan jaringan yang terbuka antar perguruan tinggi secara internasional. Penelitian terdahulu membuktikan bahwa internasionalisasi perguruan tinggi mampu meningkatkan reputasi perguruan tinggi di tingkat global (Delgado-Márquez, Escudo-Torres \& Hurtado-Torres, 2013). Peluang ini dapat digunakan oleh perguruan tinggi di Indonesia untuk semakin dikenal dan mencegah terjadinya brain drain karena para tenaga ahli yang berasal dari Indonesia tidak perlu pergi ke luar negeri untuk dapat mengembangkan potensinya.

Berdasarkan laporan investigasi GATRA (10 oktober 2003) menyebutkan bahwa Lembaga IImu Pengetahuan Indonesia (LIPI) telah kehilangan 27 penelitinya saat menjadi karyasiswa di luar negeri. Hal tersebut belum termasuk banyaknya dosen dan peneliti yang tidak kembali ke Indonesia setelah disekolahkan dengan uang negara. Kenyataan ini selaras dengan apa yang terjadi di ITB dimana sepanjang tahun 2000-2003 kehilangan 26 dosen telah mengundurkan diri dari ITB untuk menerima tawaran kerja di luar negeri (June.C, 2011). Banyaknya tenaga ahli yang memilih untuk meninggalkan Indonesia perlu dijadikan sebagai bahan intropeksi kualitas pendidikan Indonesia. Fakta-fakta ini telah menunjukkan brain drain telah berkembang secara subur di Indonesia. Apabila hal ini dibiarkan terus menerut Indonesia, maka setiap tahun negara ini akan kehilangan tenaga ahli potensial di masa mendatang. Hal ini akan menghambat kemajuan bangsa karena rendahnya kualitas pendidikan negara ini.

Fenomena brain drain di Indonesia umumnya terjadi saat seseorang telah menerima kesempatan untuk berinteraksi studi di luar negeri (June. C, 2011). Interaksi yang dilakukan 
seseorang saat melakukan studi melahirkan konsep profesionalisme pada dirinya karena di negara dengan kualitas pendidikan yang tinggi memilki budaya organisasi yang mapan, prosedur kerja yang teratur dan etos kerja yang tinggi. Kesempatan untuk mengembangkan potensi yang lebih luas membuka jalan bagi para tenaga ahli untuk berkarier di luar negeri. Sebagai negara yang berkembang Indonesia memerlukan para tenaga ahli untuk meningkatkan kualitas pendidikannya karena tolak ukur dari kemajuan bangsa berawal dari seberapa baik kuaitas pendidikan yang dimiliki. Dengan adanya internasionalisasi perguruan tinggi sebagai suatu upaya untuk mencegah semakin suburnya brain drain di Indonesia diharapkan para tenaga ahli tidak meninggalkan negaranya sendiri.

Internasionalisasi perguruan tinggi tidak dapat berjalan apabila calon mahasiswa tidak mengetahui standard apa yang dimiliki perguruan tinggi di Indonesia sehingga mereka memilih untuk melanjutkan pendidikannya ke luar negeri dan kemudian tidak kembali ke Indonesia. Adanya perguruan tinggi yang berstandar internasional di Indonesia akan membantu terjadinya pencegahan brain drain di Indonesia. Pengenalan internasionalisasi perguruan tinggi kepada para calon mahasiswa yang nantinya akan melanjutkan ke jenjang pendidikan yang lebih tinggi dapat membantu dalam pencegahan brain drain di Indonesia. Dengan pengetahuan tersebut, calon mahasiswa diharapkan tidak perlu meninggalkan negaranya sendiri karena di Indonesia berbagai perguruan tinggi telah menetapkan skala Internasional sebagai standard pendidikannya. Sehingga potensi-potensi generasi penerus bangsa dapat dikembangkan di negaranya sendiri sebagai upaya merealisasikan kemajuan bangsa Indonesia di bidang pendidikan khususnya perguruan tinggi. Hal ini seperti terjadi di Singapura. Menurut penelitian Ziguras and Greble (2015) Singapura memerkuat perguruan tingginya supaya berskala internasional untuk membendung fenomena brain drain yang terjadi di negaranya.

Proses internasionalisasi perguruan tinggi merupakan respons adaptif terhadap konteks global yang ditandai oleh globalisasi (Sánchez-Tarragó, N. dkk, 2017). Salah satu aspek yang mendukung dalam proses internasionalisasi yaitu kemampuan para calon mahasiswa dalam literasi informasi tentang perguruan tinggi berskala internasional. Pada hakikatnya literasi informasi adalah seperangkat keterampilan yang diperlukan untuk mencari, menelusur, menganalisis, dan memanfaatkan informasi (Bundy, 2001). Literasi informasi perlu bagi internasionalisasi perguruan tinggi karena mempermudah calon mahasiswa dalam memilih perguruan tinggi yang berskala internasional (Hughes. $\mathrm{H}, 2005$ ). Literasi informasi menentukan banyaknya informasi yang akan diserap seseorang agar tidak mudah diperdaya oleh informasi. Saat seseorang tidak mudah untuk diperdaya informasi maka ia akan berpikir kritis sehingga dapat meningkatkan kualitas diri. Dengan memiliki keterampilan ini diharapkan seseorang dapat memiliki kemampuan untuk memanfaatkan segala informasi secara tepat dan benar. Pemanfaatan teknologi dan informasi dan literasi di perguruan tinggi secara tepat dapat meningkatkan transformasi pendidikan karena para mahasiswa akan memilih sesuatu yang 
mereka inginkan (Mamo. Y, 2011). Ketersediaan sumber daya informasi merupakan faktor penting dalam dunia perguruan tinggi terlebih pada proses internasionalisasi. Berdasarkan paparan tersebut maka dapat dinyatakan bahwa literasi informasi dapat mencegah fenomena brain drain di Indonesia. Karena dengan semakin meleknya informasi para calon mahasiswa tentang kualitas perguruan tinggi di Indonesia maka fenomena brain drain di negara ini akan semakin berkurang.

Fenomena brain drain menuntut kesadaran intelektual bagi suatu negara yang ditinggalkan oleh para tenaga ahlinya. Pada era teknologi seperti ini tidak dapat dipungkiri pendidikan menjadi prioritas utama setiap individu. Lahirnya internasionalisasi dalam perguruan tinggi menjadi acuan bagi bangsa untuk meningkatkan kualitas pendidikan yang masih rendah agar tidak semakin ditinggalkan oleh para tenaga ahlinya karena telah berinteraksi dengan pendidikan di luar negeri. Pada masa keemasan teknologi informasi saat ini masuknya informasi semakin luas dan kompleks dibutuhkan literasi informasi sebagai suatu keterampilan dasar yang penting untuk dikuasai agar tidak kehilangan peluang. Kemampuan mendasar ini idealnya menjadi modal yang dimiliki agar masing-masing individu dapat mencapai hidup yang lebih produktif dan lebih berkualitas (Lis. S, 2015) termasuk di dalamnya memilih perguruan tinggi dalam negeri yang berskala internasional. Penelitian ini bertujuan untuk mengetahui gambaran literasi informasi siswa SMA berkaitan dengan internasionalisasi perguruan tinggi. Dengan diketahuinya gambaran literasi informasi siswa SMA tentang internasionalisasi perguruan tinggi dapat diperoleh kondisi awal tentang kemampuan calon mahasiswa dalam mengetahui perguruan tinggi berskala internasional. Pengetahuan tentang literasi informasi tentang perguruan tinggi berskala internasional itu pada akhirnya akan mampu membendung terjadinya brain drain di Indonesia.

Penelitian ini bertujuan untuk mengetahui gambaran literasi informasi siswa SMA berkaitan dengan internasionalisasi perguruan tinggi. Masih sedikitnya penelitian tentang literasi informasi oleh karena itu dilakukan untuk memberikan gambaran awal. Dengan begitu dapat dijadikan sebagai landasan untuk penelitian selanjutnya.

\section{Metode Penelitian}

Penelitian untuk mendapatkan gambaran awal tentang literasi informasi pelajar SMA tentang internasionalisasi perguruan tinggi. Oleh karena itu penelitian ini digolongkan ke dalam penelitian deskriptif karena hanya melibatkan satu variable saja yaitu literasi informasi pelajar SMA. Penelitian dengan satu variable kuantitatif tanpa membuat perbandingan, atau menghubungkan dengan variabel yang lain. dapat digolongkan ke dalam penelitian deskriptif (Sugiyono, 2012: 13). Untuk memberikan gambaran tentang variable tersebut, teknik analisa data yang digunakan oleh peneliti menggunakan metode statistik deskriptif. Metode ini biasa digunakan untuk menampilkan data dalam bentuk grafik dan diagram untuk mempermudah 
pembaca dalam memahami data yang diperoleh oleh peneliti (McNabb, 2006).

Sebagai penelitian awalan (pilot study) maka penelitian ini menggunakan metode sampel aksidental yang tepat digunakan untuk studi eksplorasi pendahuluan (Neuman, 2016). Sampel yang dipilih adalah dua sekolah yang merupakan sekolah unggulan di kota Solo. Kota Solo dipilih karena memiliki beberapa perguruan tinggi negeri maupun swasta yang sudah memiliki standar internasional. Selain itu lokasi ini dipilih karena berdekatan dengan lokasi peneliti berada sehingga tidak diperlukan biaya yang besar untuk melakukan sebuah studi pendahuluan. Data dikumpulkan dengan cara survey menggunakan kuesioner. Responden diminta mengisi persepsi mereka terhadap instrumen-instrumen internasionalisasi dengan menggunakan lima skala Likert mulai dari sangat tidak setuju, tidak setuju, netral, setuju dan sangat setuju.

Untuk mengukur literasi informasi perguruan tinggi berskala internasional, penelitian ini menggunakan pengukuran yang digunakan oleh system perankingan QS Stars. System ini dipilih karena sudah dipergunakan dalam penelitian sebelumnya di Indonesia (Astuti, Pratolo \& Anwar, 2017) dan merupakan salah satu system perangkingan universitas skala internasional yang paling produktif di antara perangkingan yang lain (Rauhvargers, 2014). Perangkingan QS didasarkan pada enam kriteria yaitu: Reputasi Akademis (Academic Reputation), Reputasi Pemberi Kerja (Employer Reputation), Rasio Fakultas/Mahasiswa (Faculty/Student Ratio), Sitasi per Fakultas (Citations per Faculty) dan Rasio Fakultas Internasional/ Rasio Mahasiswa Internasional (International Faculty Ratio/International Student Ratio) (QS World University Ranking, 2018).

\section{Hasil Penelitian}

Pada bagian ini akan dipaparkan hasil penelitian. Pemaparan hasil diawali dengan paparan data dasar dan diikuti dengan masing-masing instrumen internasionalisasi berdasarkan lembaga perankingan QS. Beberapa instrument disesuaikan dengan konteks penelitian agar mendapatkan makna yang sesuai.

\section{A. Deskripsi Responden}

Penelitian dilakukan di dua sekolah dengan predikat unggulan di Kota Solo. Sekolah unggulan dipilih dengan asumsi bahwa siswa-siswi di sekolah ini memiliki kemampuan dan kemauan yang memadai untuk dapat melanjutkan ke perguruan tinggi berskala internasional. Survei dilakukan dengan cara mendatangi dua sekolah tersebut dan memilih dua kelas dengan dua penjurusan yang berbeda yaitu IPA dan IPS. Dari dua sekolah unggulan tersebut didapat 41 laki-laki dan 57 perempuan yang mengisi survey. Sebagaimana digambarkan pada Gambar 1. 


\section{Gambar 1. Deskripsi Responden}

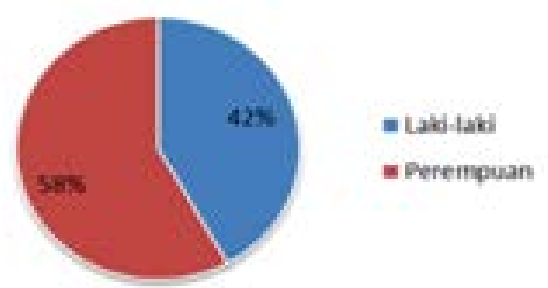

Sumber : olah data peneliti

\section{B. Minat dan Ranking Internasional}

Sebelum beralih ke pertanyaan instrumen, responden ditanya tentang dua data dasar yaitu minat mereka untuk melanjutkan sekolah di perguruan tinggi dalam negeri berskala internasional dan persetujuan mereka tentang alasan ranking internasional. Jawaban mereka menunjukkan bahwa mayoritas menyetujui nya (sangat setuju=11, setuju=38), 34 diantaranya bersikap netral dan 15 diantaranya tidak menyetujuinya (sangat tidak setuju=2, tidak setuju=13). Rincian minat responden ditunjukkan dalam Gambar 2.

Gambar 2. Minat Bersekolah di Perguruan Tinggi Dalam Negeri Berskala Internasional

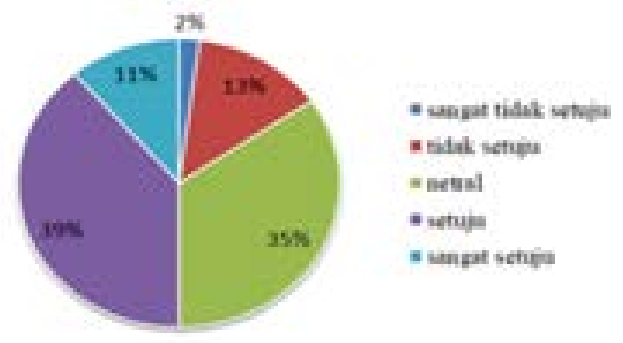

Sumber: olah data peneliti

Pertanyaan pembuka kedua berkisar tentang apakah ranking internasional sebuah perguruan tinggi menjadi alasan mereka dalam memilih studi lanjut. Jawaban mayoritas dari pelajar SMA tersebut adalah 75 setuju menjadikan ranking internasional sebagai alasan memilih perguruan tinggi (sangat setuju $=25$, setuju $=50$ ), dengan jawaban netral tidak lebih dari 20 anak dan 3 anak menyatakan tidak setuju. Hasil tersebut ditampilkan dalam Gambar 3.

Gambar 3. Ranking Internasional sebagai Alasan Memilih Perguruan Tinggi

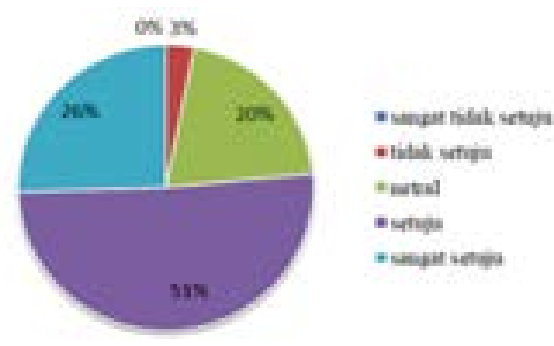

Sumber: olah data peneliti 


\section{Instrumen QS}

Pemaparan hasil berikutnya berdasarkan pada instrumen internasionalisasi yang dikembangkan oleh lembaga pemeringkat perguruan tinggi internasional QS.

\section{- Reputasi Akademis}

Reputasi akademis menurut QS adalah reputasi sebuah perguruan tinggi menurut para akademisi di seluruh dunia. Untuk memperoleh reputasi ini QS mengirim survey kepada beberapa akademisi untuk mendapatkan nilai dari perguruan tinggi yang akan di rangking (QS World University Ranking, 2018). Pada penelitian ini siswa ditanyakan berkaitan reputasi akademik secara internasional menjadi alasan mereka dalam memilih perguruan tinggi. Jawaban mayoritas dari responden tersebut adalah 78 setuju menjadikan reputasi internasional sebagai alasan memilih perguruan tinggi (sangat setuju $=29$, setuju $=49$ ), dengan jawaban netral sebesar 17 siswa anak dan 3 siswa menyatakan tidak setuju.

Gambar 4. Reputasi Akademik sebagai Alasan Memilih Perguruan Tinggi

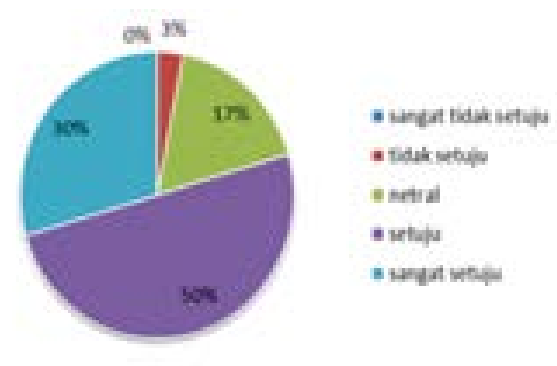

Sumber: olah data peneliti

\section{- Reputasi Pemberi Kerja}

Reputasi pemberi kerja menurut QS adalah reputasi lulusan perguruan tinggi di mata pemberi kerja. Untuk memperoleh reputasi ini QS menanyakan ke beberapa pemberi kerja di seluruh dunia, perguruan tinggi manakah yang paling memberikan pekerja terbaik di organisasi mereka (QS World University Ranking, 2018). Seperti halnya pada instrument sebelumnya siswa SMA ditanyakan apakah mereka akan memilih perguruan tinggi yang memiliki reputasi baik di mata pemberi kerja. Hasil menunjukkan bahwa 29 siswa menyatakan persetujuannya untuk memilih universitas yang mampu memberikan masukan lulusan yang baik ke dunia kerja (setuju=23, sangat setuju $=6$ ) sedangkan yang tidak melihat bahwa reputasi perguruan tinggi di dunia kerja penting sebagai alasan memilih perguruan tinggi hanya 4 siswa (tidak setuju=2, sangat tidak setuju=2). Gambaran tentang persetujuan siswa terhadap penggunaan reputasi pemberi kerja sebagai alasan mereka memilih perguruan tinggi dapat dilihat pada Gambar 5. 
Gambar 5. Reputasi Pemberi Kerja sebagai Alasan Memilih Perguruan Tinggi

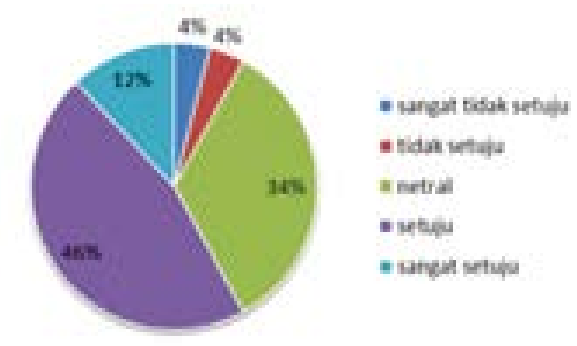

Sumber: olah data peneliti

\section{- Rasio Fakultas/Mahasiswa}

Selain memperhatikan tingkat popularitas di dunia internasional, QS juga memperhatikan kualitas internal sebuah perguruan tinggi. Salah satu instrument untuk mengukur efektivitas belajar adalah dengan melihat berapa jumlah mahasiswa dibandingkan jumlah staff pengajarnya. Semakin banyak staff pengajar yang melayani mahasiswa maka kualitas sebuah perguruan tinggi akan semakin baik (QS World University Ranking, 2018). Pada penelitian ini siswa ditanya apakah mereka setuju jika menjadikan rasio jumlah pengajar/mahasiswa sebagai patokan untuk memilih perguruan tinggi. Jawaban di instrument ini agak berbeda sebagian besar (41 siswa) tidak menyatakan setuju atau tidak setuju terhadap instrument ini. Sedangkan yang menyatakan persetujuannya adalah 37 siswa (setuju=32, sangat setuju =5) dan yang tidak setuju terhadap instrument ini adalah 20 (tidak setuju=19 dan sangat tidak setuju =1). Persentase dari instrument ini dapat dilihat pada Gambar 6.

Gambar 6. Rasio Fakultas/Mahasiswa sebagai Alasan Memilih Perguruan Tinggi

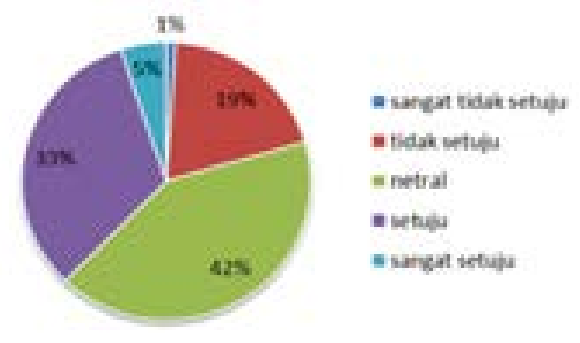

Sumber: olah data peneliti

\section{- Sitasi per Fakultas}

Untuk menjamin kualitas perguruan tinggi selain aspek pengajaran QS juga menaruh perhatian pada aspek penelitian. Pada hal ini QS melihat seberapa banyak sebuah hasil penelitian berupa publikasi dari sebuah perguruan tinggi yang dirujuk/disitasi oleh publikasi lain (QS World University Ranking, 2018). Pada konteks penelitian ini peneliti menanyakan apakah para siswa 
SMA menjadikan jumlah sitasi publikasi sebagai alasan untuk memilih perguruan tinggi? Serupa dengan rasio fakultas/mahasiswa, disini mayoritas pelajar SMA juga bersikap netral (62 siswa) terhadap sitasi publikasi sebagai alasan mereka memilih perguruan tinggi. Sisanya 32 siswa setuju (setuju=28, sangat setuju $=4$ ) dan 4 siswa tidak setuju terhadap jumlah sitasi publikasi sebagai alasan untuk memilih perguruan tinggi.

Gambar 7. Sitasi per Fakultas sebagai Alasan Memilih Perguruan Tinggi

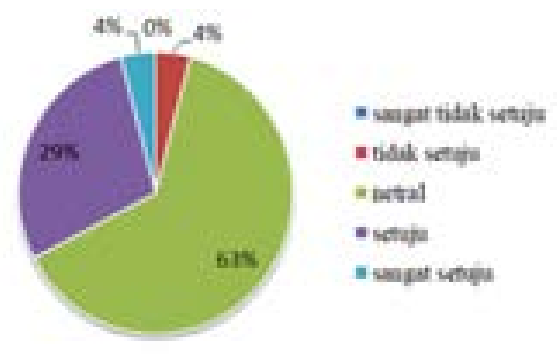

Sumber: olah data peneliti

\section{- Rasio Fakultas Internasional/Rasio Mahasiswa Internasional}

Instrument ini kembali mengukur kadar internasional pada sebuah perguruan tinggi. QS menggunakan kata fakultas sebagai representasi staff pengajar. Di sini rasio staff pengajar yang berkewarganegaraan asing dibandingkan dengan staff pengajar lokal menjadi tolok ukur apakah sebuah perguruan tinggi bisa dikatakan berkelas internasional. Selain itu QS juga melihat seberapa banyak perbandingan antara mahasiswa internasional dengan mahasiswa local. Asumsi yang mereka gunakan adalah bahwa adanya staff pengajar dan mahasiswa internasional akan meningkatkan lingkungan internasional di sekitar mahasiswa sehingga akan meningkatkan kemampuan dan softskill mahasiswa (QS World University Ranking, 2018). Untuk rasio fakultas internasional, siswa SMA yang disurvei memiliki jumlah yang hampir sama untuk pendapat netral (38 siswa) dan setuju (setuju=41 siswa, sangat setuju=7 siswa). Gambaran tentang rasio fakultas internasional dapat dilihat pada Gambar 8.

Gambar 8. Rasio Fakultas Internasional sebagai Alasan Memilih Perguruan Tinggi

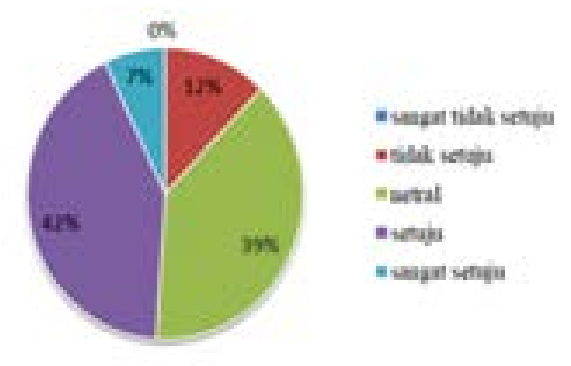

Sumber: olah data peneliti 
Untuk rasio mahasiswa internasional, siswa SMA ditanya apakah mereka akan memilih perguruan tinggi yang memiliki banyak jumlah mahasiswa internasional? Mayoritas responden menjawab netral ( 60 siswa) sedangkan sisanya setuju (setuju=18 siswa, sangat setuju=3 siswa) dan tidak setuju (17 siswa). Gambar tentang rasio mahasiswa internasional bias dilihat pada gambar 9.

Gambar 9. Rasio Mahasiswa Internasional sebagai Alasan Memilih Perguruan Tinggi

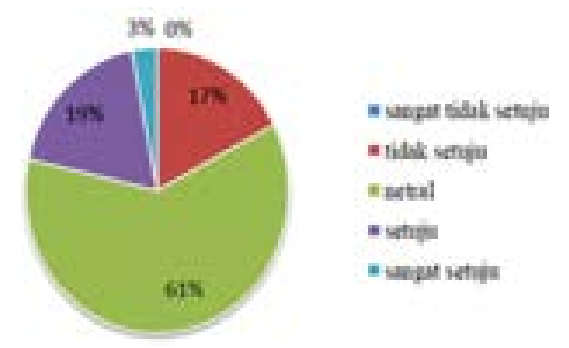

Sumber: olah data peneliti

\section{Pembahasan}

Berdasarkan temuan survey tentang alasan siswa SMA memilih perguruan tinggi dapat disimpulkan bahwa para calon mahasiswa tersebut memiliki minat untuk melanjutkan studi di perguruan tinggi dalam negeri yang berskala internasional. Hal ini tentu merupakan sesuatu yang baik karena dengan adanya minat ini fenomena brain drain di masa mendatang akan berkurang. Alasan mereka untuk berminat melanjutkan ke perguruan tinggi berskala internasional berhubungan dengan ranking perguruan tinggi tersebut secara internasional. Ini menunjukkan bahwa apabila perankingan internasional disampaikan kepada para siswa SMA dapat meningkatkan minat mereka untuk melanjutkan studi lanjut di dalam negeri dengan perguruan tinggi berskala internasional. Dua data tentang minat dan ranking internasional sebagai alasan untuk memilih perguruan tinggi dalam negeri berskala internasional ini memberikan gambaran bahwa sebenarnya para calon mahasiswa juga berminat pada perguruan tinggi dalam negeri dan juga melihat ranking perguruan tinggi berskala internasional sebagai salah satu alasan mereka memilih perguruan tinggi dalam negeri. Berdasarkan hasil ini dapat disimpulkan bahwa literasi informasi responden terhadap kualitas pendidikan tinggi berskala internasional sudah baik, terbukti dari tingginya minat dan tingkat persetujuan mereka tentang ranking internasional perguruan tinggi.

Berdasarkan instrumen internasionalisasi dapat disimpulkan beberapa hal sebagai berikut. Pertama untuk indikator reputasi akademik, para siswa melihat bahwa reputasi akademis di skala internasional menjadi alasan mereka untuk memilih perguruan tinggi. Indikator ini merupakan satu-satunya indikator dimana para pelajar SMA memiliki tingkat persetujuan diatas $75 \%$. Ini menunjukkan bahwa mereka memiliki literasi informasi yang baik tentang pentingnya reputasi internasional bagi kualitas sebuah perguruan tinggi. Temuan ini 
sejalan dengan penelitian Soutar dan Turner (2002) yang juga menemukan reputasi akademis sebagai salah satu faktor yang menentukan seorang calon mahasiswa memilih perguruan tinggi.

Seperti halnya dengan reputasi akademik, untuk instrument QS yang kedua yaitu reputasi pemberi kerja, mayoritas responden dalam survey ini memberikan sikap persetujuannya. Mereka mengganggap reputasi pemberi kerja merupakan salah satu alasan bagi mereka untuk memilih perguruan tinggi, tempat mereka bekerja nantinya. Berdasarkan temuan ini dapat dikatakan bahwa literasi informasi responden terhadap kaitan antara pendidikan tinggi dengan dunia kerja sudah baik, ini dibuktikan dengan mayoritas pendapat mereka yang menjadikan reputasi pemberi kerja sebagai salah satu alasan untuk memilih perguruan tinggi. Reputasi pemberi kerja menjamin bahwa alumni perguruan tinggi tertentu akan medapatkan pekerjaan yang layak. Penelitan sebelumnya juga menemukan bahwa prospek pekerjaan adalah alasan para pelajar sekolah untuk memilih perguruan tinggi tertentu (Soutar \& Turner, 2002; HemsleyBrown, 2012).

Satu instrument lain yaitu rasio fakultas internasional juga menunjukkan hasil literasi informasi yang baik. Rasio ini menunjukkan jumlah staf pengajar internasional yang ada di perguruan tinggi. Hasil survey juga menunjukkan bahwa adanya staff pengajar internasional menjadi alasan para responden untuk memilih perguruan tinggi negeri. Adanya staff pengajar internasional merupakan penanda kualitas dari sebuah perguruan tinggi (Horta, 2009). Ini menunjukkan responden sudah sadar pentingnya keberadaan staff pengajar berskala internasional dalam menjamin kualitas pendidikan tinggi.

Hasil agak berbeda diperoleh dari tiga instrumen QS lainnya. Untuk instrument QS rasio fakultas/mahasiswa, para responden mayoritas memberikan jawaban netral terhadap kedua instrument ini. Hasil ini bisa saja menunjukkan bahwa para responden tidak mengetahui kualitas perguruan tinggi tidak hanya dipengaruhi oleh reputasi perguruan tinggi tersebut saja tetapi juga dipengaruhi oleh perbandingan (rasio) antara jumlah staff pengajar dan mahasiswa. Sebagaimana diutarakan dalam penelitian sebelumnya bahwa kualitas rasio staff pengajar dan mahasiswa yang kecil akan meningkatkan kualitas pendidikan tinggi (Arubayi, 2009). Hal ini disebabkan oleh rasio kecil akan meningkatkan kualitas interaksi antara staff pengajar dan mahasiswa (Chepcieng, Mbugua \& Kariuki, 2006). Hasil survey ini mengindikasikan responden tidak memiliki informasi yang memadai untuk menganggap hal rasio staff pengajar terhadap mahasiswa adalah suatu hal yang penting bagi kualitas perguruan tinggi. Oleh karena itu dapat disimpulkan bahwa literasi informasi para responden terhadap pentingnya instrument rasio staff pengajar/mahasiswa masih kurang.

Sama halnya dengan rasio fakultas/mahasiswa, sitasi per fakultas juga mendapatkan pendapat mayoritas netral dari responden. Sitasi ini sebenarnya menggambarkan kualitas penelitian para staff pengajar di perguruan tinggi (Delgado-Marquez, Hurtado-Torres, \& 
Bondar, 2011). Hasil ini mengindikasikan bahwa literasi informasi responden tentang bahwa kualitas penelitian menentukan kualitas sebuah perguruan tinggi belum mencukupi.

Jumlah mahasiswa asing merupakan salah satu komponen terpenting dalam internasionalisasi pendidikan tinggi (Blight, Davis \& Olsen, 1999). Penelitian sebelumnya menunjukkan bahwa jumlah mahasiswa asing menjadi penanda kualitas perguruan tinggi (Horta, 2009). Sayangnya, para responden belum memandang instrumen ini sebagai alasan yang penting untuk memilih perguruan tinggi. Seperti halnya dua instrumen sebelumnya, pada instrument ini literasi informasi para responden tampaknya belum baik, karena mereka masih terkesan ragu dalam menjawab pertanyaan tentang isu ini dengan mayoritas menjawab netral.

Bahasan di atas menunjukkan bahwa responden sudah memiliki literasi informasi terhadap beberapa instrumen internasionalisasi sebuah perguruan tinggi. Instrumen seperti reputasi akademik, reputasi pemberi kerja dan rasio staf pengajar internasional merupakan tiga instrumen yang sudah dipahami oleh responden. Sedangkan tiga instrument lainnya yaitu rasio staff pengajar/mahasiswa, sitasi staff pengajar dan rasio mahasiswa asing/domestic menjadi instrumet yang tampaknya belum dipahami benar oleh para responden. Berdasarkan hasil ini dapat dinyatakan bahwa literasi informasi pelajar SMA yang menjadi responden dalam penelitian dalam instrument internasionalisasi perguruan tinggi sudah cukup baik. Mayoritas responden dapat menentukan jawaban dengan pasti sebanyak tiga dari enam instrumen yang diajukan oleh QS sebagai instrumen internasionalisasi. Untuk tiga instrumen lain perlu diberikan informasi yang lebih agar para calon mahasiswa tersebut memiliki literasi yang lebih baik tentang kualitas internasional sebuah perguruan tinggi.

Untuk dapat memberikan literasi informasi yang lebih baik untuk setiap instrument internasionalisasi QS di atas penelitian ini juga mengkaji media apakah yang paling sering digunakan oleh para responden untuk mencari informasi. Hasil dari pertanyaan tersebut ditampilkan pada Gambar 10.

Gambar 10. Media yang Digunakan Responden untuk Mencari Informasi

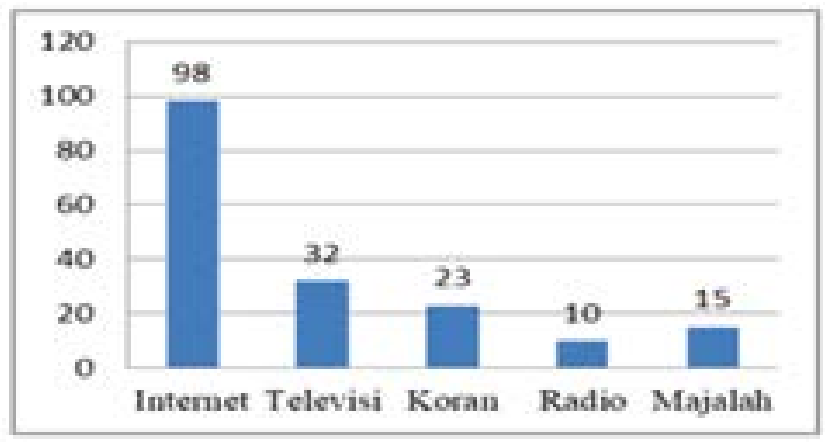

Sumber: olah data peneliti 
Gambar 10 menunjukkan bahwa responden yang notabene pelajar SMA menggunakan Internet, televisi, koran, dan majalah sejalan dengan temuan penelitian sebelumnya tentang media yang digunakan untuk mencari informasi tentang internasionalisasi perguruan tinggi (Bodycott, 2009). Radio menjadi temuan tambahan sebagai media yang digunakan untuk mencari informasi bagi para calon mahasiswa. Hasil tersebut menunjukkan bahwa mayoritas menggunakan Internet sebagai media untuk mencari informasi. Penelitian sebelumnya dari Ooi, Ho dan Amri (2010) juga menunjukkan bahwa Internet merupakan media yang paling tepat untuk mencari informasi tentang internasionalisasi perguruan tinggi. Berdasarkan temuan ini dan penelitian sebelumnya dapat dinyatakan bahwa Internet adalah media yang paling tepat untuk meningkatkan literasi informasi para calon mahasiswa tentang internasionalisasi perguruan tinggi.

\section{Simpulan dan Saran}

Fenomena brain drain berpotensi menghambat pembangunan suatu bangsa karena potensipotensi sumber daya manusia pindah ke negara lain. Untuk mengatasi fenomena tersebut perlu dilakukan internasionalisasi perguruan tinggi dalam negeri. Tetapi itu saja tidak cukup, para calon mahasiswa yaitu pelajar SMA tingkat akhir perlu memiliki literasi informasi mengenai internasionalisasi perguruan tinggi dalam negeri. Jika literasi informasi baik, maka besar kemungkinan pelajar SMA tersebut akan tetap bersekolah di dalam negeri dan mengurangi fenomena brain-drain di suatu negara.

Penelitian ini dilakukan sebagai studi awalan untuk menangkap persepsi siswa SMA terhadap internasionalisasi perguruan tinggi. Hasil menunjukkan bahwa para calon mahasiswa itu memiliki literasi informasi yang cukup baik tentang internasionalisasi perguruan tinggi. Responden dalam penelitian ini bisa mengambil sikap jelas dalam tiga dari enam indikator internasionalisasi perguruan tinggi, yaitu reputasi akademis, reputasi pemberi kerja dan rasio fakultas internasional.

Penelitian ini secara praktis menyarankan penggunaan Internet sebagai media yang dapat meningkatkan literasi pelajar SMA untuk tiga indicator internasionalisasi lainnya. Hal ini dikarenakan media Internet adalah media yang paling banyak digunakan oleh mereka. Secara metodologis penelitian ini menyarankan penelitian selanjutnya untuk menggunakan sampel yang lebih luas untuk mendapatkan generalisasi hasil yang lebih baik.

\section{Ucapan Terima Kasih}

Penulis mengucapkan terima kasih kepada LPPM UNS yang sudah memberikan Hibah Pengabdian Kepada Masyarakat Tahun 2018. 


\section{Daftar Pustaka}

Alemu, S. K. (2014). An appraisal of the internationalisation of higher education in sub-Saharan Africa. Center for Educational Policy Studies Journal, 4(2), 71-90.

Arubayi, D. O. (2009). Lecturer Quality, Quantity and Gender in Colleges of Education in Nigeria. College Student Journal, 43(2).

Astuti, R. J., Pratolo, S., \& Anwar, M. (2017). College performance based on QS-stars method: Model designing of college performance through knowledge management system (empirical study on a accreditation colleges in java). International Journal of Applied Business and Economic Research, 15(16), 389-402. Retrieved from www.scopus.com.

Blight, D., Davis, D., \& Olsen, A. (1999). The internationalisation of higher education. Higher education through open and distance learning, 15-31.

Bodycott, P. (2009). Choosing a higher education study abroad destination: What mainland Chinese parents and students rate as important. Journal of research in International education, 8(3), 349-373.

Bundy, A. (2001). For a clever country: information literacy diffusion in the 21st century (Doctoral dissertation).

Cahyaningtyas, J. (2018). Brain Drain di Indonesia. Paradigma, 15(2).

Chepchieng, M. C., Mbugua, S. N., \& Kariuki, M. W. (2006). University students perception of lecturer-student relationships: a comparative study of Public and Private Universities in Kenya. Educational Research and Reviews, 1(3), 80-84.

De Wit, H. (2015). Recent trends and issues in international student mobility. International Higher Education, (59).

Delgado-Márquez, B. L., Escudero-Torres, M. A., \& Hurtado-Torres, N. E. (2013). Being highly internationalised strengthens your reputation: an empirical investigation of top higher education institutions. Higher Education, 66(5), 619-633.

Delgado-Márquez, B. L., Hurtado-Torres, N. E., \& Bondar, Y. (2011). Internationalization of higher education: Theoretical and empirical investigation of its influence on university institution rankings. International Journal of Educational Technology in Higher Education, 8(2), 265284.

Giousmpasoglou, C., \& Koniordos, S. K. (2017). Brain drain in higher education in Europe: Current trends and future perspectives.

Hemsley-Brown, J. (2012). 'The best education in the world': reality, repetition or cliché? International students' reasons for choosing an English university. Studies in Higher Education, 37(8), 1005-1022.

Horta, H. (2009). Global and national prominent universities: internationalization, competitiveness and the role of the State. Higher Education, 58(3), 387-405. 
Hughes, H. (2005). Actions and reactions: exploring international students' use of online information resources. Australian Academic \& Research Libraries, 36(4), 169-179.

Lee, W. O. (2014). Academic migration and reshaping of pedagogy and epistemology: An insider-outsider perspective. In Academic Migration, Discipline Knowledge and Pedagogical Practice (pp. 161-175). Springer, Singapore.

Mammo, Y. (2011). Rebirth of library and information science education in Ethiopia: Retrospectives and prospectives. The International Information \& Library Review, 43(2), 110-120.

Rauhvargers, A. (2014). Where are the global rankings leading us? An analysis of recent methodological changes and new developments. European Journal of Education, 49(1), 29 44.

Sánchez-Tarragó, N., Castellanos-Gallardo, I., \& Bufrem, L. S. (2017). Academic library contributions to internationalization: a systematic review. Perspectivas em Ciência da Informação, 22(3), 186-209.

Setyowati, L. (2015). Literasi Informasi Dilihat dari Perspektif Modal Manusia. LIBRARIA: Jurnal Perpustakaan, 3(2), 232-2.

Sieglin, V., \& Zúñiga, M. (2010). “Brain Drain” In Mexico Case Study On Job Expectations And Willingness To Labor Migration Students Of Engineering And Natural Sciences. Perfiles Educativos, 32(128), 55-79. 